\title{
Surfactant-free synthesis of carbon-supported silver (Ag/C) nanobars as an efficient electrocatalyst for alcohol tolerance and oxidation of sodium borohydride in alkaline medium
}

\author{
Santanu Dey ${ }^{1} \cdot$ Pradipta Chakraborty $^{1,2} \cdot$ Dhiraj Kumar Rana $^{1} \cdot$ Subhamay Pramanik ${ }^{3} \cdot$ Soumen Basu ${ }^{1}$
}

Received: 11 November 2020 / Accepted: 20 April 2021

Published online: 10 May 2021

(c) The Author(s) 2021 OPEN

\begin{abstract}
We have synthesized carbon-supported silver $(\mathrm{Ag} / \mathrm{C})$ nanobars by a simple surfactant-free hydrothermal method using glucose as the reducing reagent as well as the source of carbon in $\mathrm{Ag} / \mathrm{C}$ nanobars. Physicochemical characterization of the materials was performed by X-ray Diffraction (XRD), field emission scanning electron microscopy, and energy-dispersive X-ray spectroscopy. The XRD pattern confirmed the presence of a pure metallic silver phase. No carbon phase was detected, which indicates that the carbon exists mainly in the amorphous form. The electrocatalytic activity of Ag/C in different electrolyte solutions such as $0.5 \mathrm{M} \mathrm{NaOH}, 0.5 \mathrm{M} \mathrm{NaOH}+1 \mathrm{M}$ ethanol (EtOH), $0.5 \mathrm{M} \mathrm{NaOH}+1 \mathrm{M}$ ethylene glycol (EG), and $0.5 \mathrm{M} \mathrm{NaOH}+0.01 \mathrm{M} \mathrm{NaBH}_{4}$ (sodium borohydride) was studied by cyclic voltammetry (CV), electrochemical impedance spectroscopy (EIS), and chronoamperometry (CA) study. Alcohol tolerance of the catalysts was also established in the presence of ethanol and ethylene glycol. The forward-to-backward current ratio from cyclic voltammetry (CV) study of Ag/C-20 $(20 \mathrm{~h})$ in $0.5 \mathrm{M} \mathrm{NaOH}+1 \mathrm{M}$ ethanol solution at $100 \mathrm{mV} \mathrm{s}^{-1}$ scan rate is 4.13 times higher compared to that of $\mathrm{Ag} / \mathrm{C}-5(5 \mathrm{~h})$. Hence, $\mathrm{Ag} / \mathrm{C}-20$ is a better candidate for the tolerance of ethanol. In the presence of ethylene glycol $(1 \mathrm{M})$ in $0.5 \mathrm{M} \mathrm{NaOH}$ solution, it is obtained that the forward-to-backward current ratio at the same scan rate for $\mathrm{Ag} / \mathrm{C}-20$ is lower than that in the presence of ethanol. The durability of the catalyst was studied by chronoamperometry measurement. We studied the electrochemical kinetics of $\mathrm{Ag} / \mathrm{C}$ catalysts for borohydride oxidation in an alkaline medium. The basic electrochemical results for borohydride oxidation show that $\mathrm{Ag} / \mathrm{C}$ has very well strength and activity for direct borohydride oxidation in an alkaline medium. The reaction of borohydride oxidation with the contemporaneous $\mathrm{BH}_{4}{ }^{-}$. hydrolysis was noticed at the oxidized silver surface. Among all the synthesized Ag/C catalysts, Ag/C-20 exhibited the best electrocatalytic performance for borohydride oxidation in an alkaline medium. The activation energy and the number of exchange electrons at $\mathrm{Ag} / \mathrm{C}-20$ electrode surface for borohydride electro-oxidation were estimated as $57.2 \mathrm{~kJ} \mathrm{~mol}^{-1}$ and 2.27 , respectively.
\end{abstract}

Keywords Carbon-supported silver (Ag/C) nanobars · Alcohol tolerance · Borohydride oxidation · Durability

\section{Introduction}

Over the last few decades, very expansive platinum $(\mathrm{Pt})$ group metals were commonly used as electrocatalysts in energy devices due to their high conductivity and less corrosion. But in the current century, researchers are searching for new cost-effective, stable, and efficient electrocatalysts to get much commercial success. Comparatively much low-priced materials such as nickel (Ni), cobalt (Co), copper (Cu), silver (Ag), and metal complexes can be

$\checkmark$ Soumen Basu, soumen.basu@phy.nitdgp.ac.in | ${ }^{1}$ Department of Physics, National Institute of Technology Durgapur, Durgapur, West Bengal 713209, India. ${ }^{2}$ Department of Physics, Bankura Sammilani College, Bankura, West Bengal 722102 , India. ${ }^{3}$ Department of Physics, Sidho Kanho Birsha University, Purulia, West Bengal 723104, India.

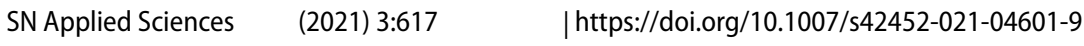


used as electrocatalysts in the alkaline medium because of the extra advantage of these to be not so much corrosive [1]. During recent few years, researchers are showing their avid interest on borohydride fuel cell because the usage of liquid fuels in these cells gives good volumetric and gravimetric energy density $[2,3]$ and authorizes a bit of large theoretical open-circuit potential of $1.64 \mathrm{~V}[2,4]$. On the other hand, sodium borohydride $\left(\mathrm{NaBH}_{4}\right)$ has high hydrogen content (10.8 wt\%), non-toxicity, low cost, and comparatively high stability in solution and solid states [5]. Fed with borohydride and alcohols like ethylene glycol or methanol in liquid fuels, it became an alternative of hydrogen in low-temperature fuel cells $[6,7]$. Even though both direct methanol fuel cell (DMFC) and direct borohydride fuel cell (DBFC) can overcome the difficulty of hydrogen storage, DBFC is far better than DMFC in case of power performance, electrochemical activity, capacity value, and theoretical open-circuit voltage at a normal temperature [8]. The DBFC is considered an encouraging energy source because of its environmental friendliness, high cell voltage, and high energy density. Furthermore, the DBFC has a lower crossover problem than that of DMFC [9]. The optimum operating conditions for direct borohydride fuel cell were studied in different reported studies focusing on how the hydrolysis was carried out $[10,11]$.

At the anode, the borohydride oxidation kinetics in the presence of an alkaline medium take place according to the following reaction:

$\mathrm{BH}_{4}^{-}+8 \mathrm{OH}^{-} \rightarrow \mathrm{B}(\mathrm{OH})_{4}^{-}+4 \mathrm{H}_{2} \mathrm{O}+8 e^{-}$

The process of complete eight-electron oxidation has a standard electrode potential of $-1.24 \mathrm{~V}$ vs. SHE, which is $0.4 \mathrm{~V}$ more negative than that of methanol or hydrogen oxidation [2]. However, at electrolyte solutions having $\mathrm{pH}<12$ in the presence of some electrocatalysts, $\mathrm{BH}_{4}{ }^{-}$hydrolysis moves along with its oxidation [12]. The parallel action of this oxidation and hydrolysis generates $\mathrm{H}_{2}$ and hydroxyborohydride ion $\left(\mathrm{BH}_{3} \mathrm{OH}^{-}\right)$, and thereupon it reduces Coulombic efficiency [2]. In direct borohydride fuel cells (DBFCs), different electrolytes can be used with the presence of suitable catalysts and the most common is sodium borohydride $\left(\mathrm{NaBH}_{4}\right)$. The oxidation reaction of borohydride is given below:

$\mathrm{BH}_{4}^{-}+x \mathrm{OH}^{-} \rightarrow \mathrm{B}(\mathrm{OH})_{4}^{-}+(x-4) \mathrm{H}_{2} \mathrm{O}+\left(4-\frac{x}{2}\right) \mathrm{H}_{2}+x e^{-}$

From the overall borohydride oxidation reaction (Eq. 2), it is expected that the effective electron numbers have been reduced to less than 8 .

It is already mentioned that platinum group metals and their alloys have colossal use as electrocatalysts for borohydride oxidation in energy devices like direct borohydride fuel cells. To make cost-effective catalysts for fuel cells, non-platinum metals have been studied for borohydride oxidation. For commercial success, silverbased electrocatalysts have drawn much attention as silver is 60 times less cost and more abundant than platinum [13]. Besides all these, silver has high conductivity, high stability, and durability. Also, it has less corrosion and oxidation in moist air.

Different morphologies of silver including nanoparticles, nanowires, nanorods, nanodendrites, and nanocubes have been prepared with the help of numerous techniques. The 1D silver nanostructure being an apposite and important building block has nabbed much attention in material science research. It is quite hard to get 1D nanostructures of silver as silver is endowed with cubic crystalline symmetry. The most common technique to construct Ag nanowires is the template method $[14,15]$. With the usage of PVP, Sun et al. synthesized the Ag/C nanocables under hydrothermal conditions [16]. Sun's group and Xia's group developed a solution-based technique to synthesize silver nanowires, showing that PVP has an important role in this nanostructure growth $[17,43]$. With that, using the hydrothermal process Qian's group demonstrated an easy preparation method of silver nanowires [18]. A polymer-assisted preparation of core-shell $\mathrm{Ag} / \mathrm{C}$ nanocables was exhibited by Wang et al. using the hydrothermal synthesis method [19]. The CTAB-assisted synthesis of carbon-supported silver nanostructures was also shown by Fang's group using hydrothermal conditions [20]. Synthesis of $\mathrm{Ag} / \mathrm{C}$ nanocables with starch acts as a source of carbon, which was reported by Yu et al. [21]. In 2008, Jin et al. reported a synthesis technique of $\mathrm{Ag} /$ polymer/carbon nanocables using glucose as carbon precursors [22], although the growth mechanism is not completely clear till now. The 1D nanostructures of $\mathrm{Ag} / \mathrm{C}$ have been developed so far with the help of some types of surfactant. In 2012, Mu et al. showed the surfactant-free synthesis of 1D carbon-supported silver nanostructure with a high aspect ratio in the presence of glucose, which plays the role of carbon source [23]. For energy device applications basically, catalysts have been prepared in a powder form and mixed with a conducting polymer solution to get the catalyst ink.

Supported metal electrocatalysts have wide use in energy devices because of the large influence of the supports on electrocatalytic activities [24]. Carbon has significant advantages like the high value of the specific surface area, long-term stability in basic and acidic media, trouble-free moderation of functional groups, and textural properties compared to other supports [25]. Therefore, a resurrection of interest has come out to synthesize a carbon-supported silver catalyst. In our work, we have followed the synthesis method of Mu et al. [23]. The 
motivation of our work was the surfactant-free synthesis of 1D carbon-supported silver nanostructures using hydrothermal conditions and studies their electrochemical characterization for borohydride oxidation in alkaline solution for the promising application in alkaline borohydride fuel cells and alcohol tolerance. The conventional parameters, which express the electrochemical activity like the oxidation-reduction current density at certain potential, the charge transfer resistance, and the stability of electrode, were measured by cyclic voltammetry (CV), electrochemical impedance spectroscopy (EIS), and chronoamperometry (CA) measurements, respectively. Stosevski et al. [1] synthesized Ag catalysts via a four-electron pathway for oxygen reduction and borohydride oxidation in an alkaline medium. They reported the value of activation energy in $2 \mathrm{M} \mathrm{NaOH}+0.03 \mathrm{M} \mathrm{NaBH}_{4}$ solution is $35 \mathrm{~kJ} \mathrm{~mol}^{-1}$. In our work, we investigated the BOR kinetics of $\mathrm{Ag} / \mathrm{C}$ having different structural morphologies, and among them, $\mathrm{Ag} / \mathrm{C}$ nanobars showed better activity. We obtained better BOR kinetics of $\mathrm{Ag} / \mathrm{C}$ catalysts in $0.5 \mathrm{M} \mathrm{NaOH}+0.01 \mathrm{M} \mathrm{NaBH}_{4}$ than that reported by Stosevski's group.

\section{Experimental}

\subsection{Chemicals and reagents}

All solutions for the experimental purpose were prepared using double distilled water. The metal precursors such as silver nitrate $\left(\mathrm{AgNO}_{3}\right)$, sodium sulfide $\left(\mathrm{Na}_{2} \mathrm{~S}\right)$, and glucose were purchased from Merck, India. All of these were analytical-grade reagents and used without further purification.

\subsection{Synthesis of $\mathrm{Ag} / \mathrm{C}$ catalysts}

The catalysts were prepared by the hydrothermal method. The synthesis details were as follows: $1.18 \mathrm{mM}$ of $\mathrm{AgNO}_{3}$ was liquefied in $40 \mathrm{ml}$ of double distilled water. Afterward, a $100 \mu \mathrm{l}(1 \mathrm{M})$ aqueous solution of $\mathrm{Na}_{2} \mathrm{~S}$ was mixed with it. The mixed solution quickly became a black solution due to the formation of Ag2S colloid. Then, the black solution was stirred for $15 \mathrm{~min}$. $2.66 \mathrm{mM}$ glucose was then added to that black solution under steady stirring. After $30 \mathrm{~min}$ of continuous stirring, the final solution was moved into a Teflon-linked stainless-steel autoclave $(100 \mathrm{ml})$. The autoclave was made airtight and kept at $175^{\circ} \mathrm{C}$ for different reaction times. After that, the sealed autoclave was cooled naturally to room temperature. We obtained a black precipitate of $\mathrm{Ag} / \mathrm{C}$ nanobars. The precipitate was washed and filtered 10 times by double distilled water and ethanol, respectively, to remove the impurities. Finally, the product was dried at $65^{\circ} \mathrm{C}$ in air and collected for the next characterizations. We prepared a set of samples with different reaction times of $5 \mathrm{~h}, 10 \mathrm{~h}, 15 \mathrm{~h}$, and $20 \mathrm{~h}$ and designated our samples as Ag/C-5, Ag/C- 10, Ag/C-15, and Ag/C-20, respectively.

\subsection{Structural characterizations of catalysts}

The X-ray diffraction (XRD) patterns of all samples were recorded by an X-ray diffractometer (Proto AXRD) using CuKa radiation $\left(1.54 \mathrm{~A}^{\circ}\right)$ for $2 \theta$ in the range of $20^{\circ}-80^{\circ}$ with step size of $0.02^{\circ}$. To get XRD patterns, all samples were coated on different glass slides by drop-casting to make films, glass slides were cleaned by water, methanol, and acetone and next sonicated in double distilled water for $15 \mathrm{~min}$ in an ultrasonic cleaner before drop-casting on these.

The field emission scanning electron micrographs and EDX of the as-prepared samples were explored by ZEISS Gemini SEM microscopy.

\subsection{Electrocatalytic measurements of catalysts}

All the electrocatalytic measurements (cyclic voltammetry, electrochemical impedance spectroscopy, chronoamperometry) of as-prepared $\mathrm{Ag} / \mathrm{C}$ samples were taken by a potentiostat/galvanostat (PGSTAT302N, Autolab, Metrohm). A platinum wire mesh and a 3.5 mol potassium chloride $(\mathrm{KCl})$ saturated $\mathrm{Ag} / \mathrm{AgCl}$ electrodes were employed as counter and the reference electrode, respectively. A glassy carbon electrode (GCE) having a $4 \mathrm{~mm}$ diameter was used as a working electrode in our work. The GCE was cleaned congruously by distilled water and ethanol all the time before each experiment. To make ready the catalyst ink, we used Nafion (Nafion ${ }^{\mathrm{TM}}$ NR 50, Merck) as a binder. $50 \mathrm{mg}$ of Nafion has dissolved appositely in $40 \mathrm{ml}$ ethanol, and then, $8 \mathrm{mg}$ of $\mathrm{Ag} / \mathrm{C}$ nanopowder was incorporated in the $1 \mathrm{ml}$ of Nafion solution. The mixture was sonicated for $15 \mathrm{~min}$ in an ultrasonic vibrator to make the catalyst ink homogeneous. To modify the GCE surface, we drop-casted $12 \mu \mathrm{l}$ catalyst ink and dried it for $2 \mathrm{~h}$ by a $100-W$ electric bulb. All the electrochemical measurements were taken at room temperature. The current densities in our work were calculated according to the geometric area $\left(0.1256 \mathrm{~cm}^{2}\right)$ of the working electrode.

\section{Results and discussion}

Characterization of $\mathrm{Ag} / \mathrm{C}$ catalysts.

Scheme 1:

$\mathrm{XRD}$ analysis and $\mathrm{Ag} / \mathrm{C}$ nanobar formation.

The phase purity and crystallinity of the synthesized $\mathrm{Ag} / \mathrm{C}$ nanostructures were analyzed by the X-ray diffraction pattern. Figure 1 exhibits the XRD patterns of all $\mathrm{Ag} / \mathrm{C}$ catalysts for preparation time of $5 \mathrm{~h}, 10 \mathrm{~h}, 15 \mathrm{~h}$, and $20 \mathrm{~h}$, 
respectively. All the XRD peaks can be indexed by Miller indices (111), (200), (220), and (311), which indicate the fcc structure of Ag. No additional phase of silver oxide was observed from the XRD pattern, but very few less intense peaks of silver sulfide were observed. It is a clear indication that all the Ag species in our sample are cubic. No extra peaks for carbon were observed, which confirmed that the carbon in our $\mathrm{Ag} / \mathrm{C}$ sample is in amorphous form. In reaction time of $5 \mathrm{~h}$, the XRD peaks illustrated that the samples were mostly Ag; very few weak peaks for silver sulfide were observed. The position of diffraction peaks for $\mathrm{Ag}$ and $\mathrm{Ag}_{2} \mathrm{~S}$ can never be changed in later synthesis times up to $20 \mathrm{~h}$. Insertion of sulfur ion reduces the rate of crystal formation by controlling the $\mathrm{Ag}^{+}$ion concentration. In our experiment, the ratio of $\mathrm{Ag}^{+}$ions to $\mathrm{S}^{-2}$ ions is nearly 5:1, although the XRD peaks of silver sulfide were extremely weaker, which confirmed that the silver sulfide colloid was reduced to metallic Ag in the presence of glucose. The intensity of XRD peaks of silver sulfide had not increased significantly in further increase of reaction times. In our synthesis technique, we guess that the growths of $\mathrm{Ag} / \mathrm{C}$ nanobars were controlled by following ways: (i) low concentration of $\mathrm{Ag}^{+}$ions controlled by silver sulfide which smooth the way for anisotropic development of silver nano-nuclei and (ii) coated layer of carbon further restricts the radial growth to form the $1 \mathrm{D}$ structure of $\mathrm{Ag} / \mathrm{C}$. The mechanism of $\mathrm{Ag} / \mathrm{C}$ nanobars formation is as follows-

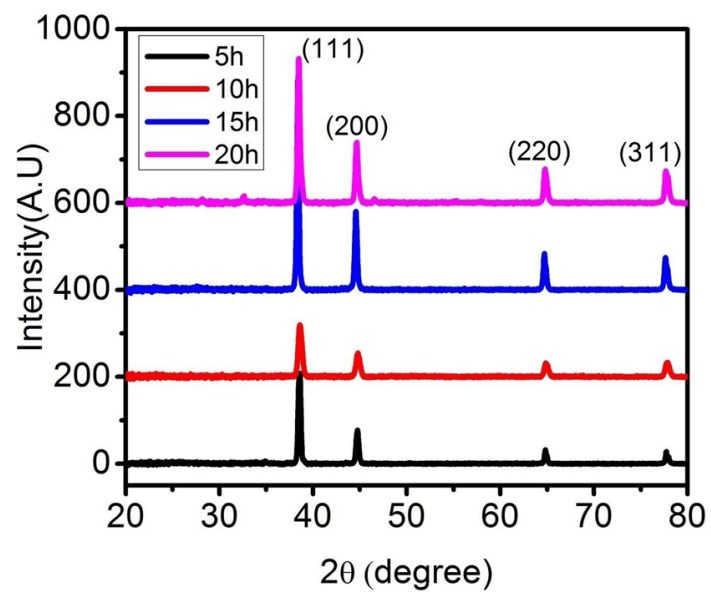

Fig. 1 XRD pattern of $\mathrm{Ag} / \mathrm{C}$ for different synthesis times obtained at $175^{\circ} \mathrm{C}$ temperature. a Ag/C-5, b Ag/C-10, c Ag/C-15, d Ag/C-20

Due to the presence of $\mathrm{S}^{2-}$ ions, the silver sulfide was produced with the following reaction:

$2 \mathrm{Ag}^{+}+\mathrm{S}^{2-} \leftrightarrow \mathrm{Ag}_{2} \mathrm{~S}$

Although the solubility of silver sulfide is excessively low, a small number of $\mathrm{Ag}^{+}$ions were released by silver sulfide. According to reaction (3), a large number of $\mathrm{Ag}^{+}$ ion were consumed, but at the same time, the silver sulfide

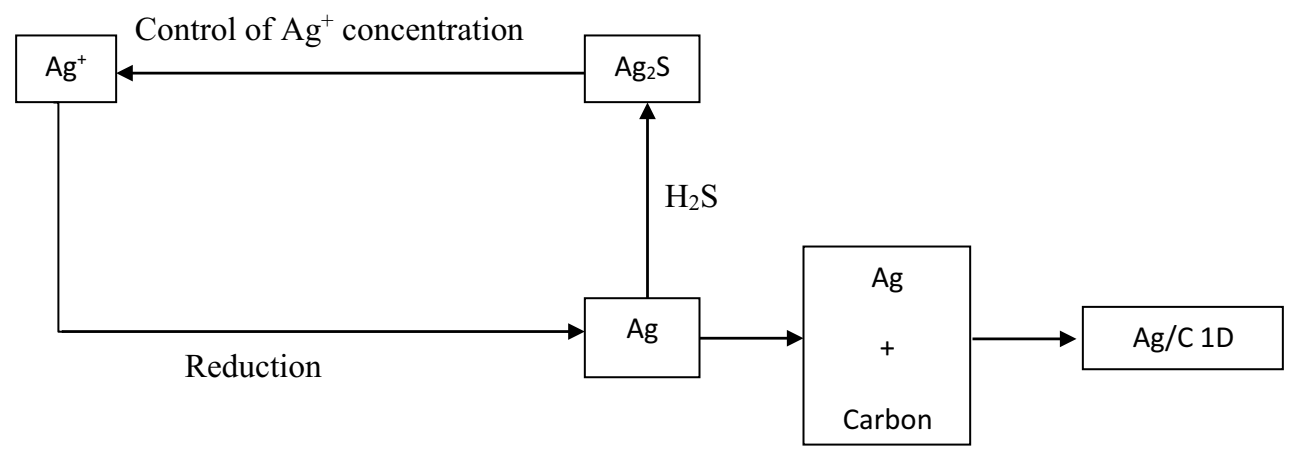

In our experiment, $\mathrm{Ag}^{+}$ions were reduced by glucose and allowed to leave a lot of $\mathrm{H}^{+}$ions at the initial stage. It can be expressed by the following reaction:

$\mathrm{CH}_{2} \mathrm{OH}-(\mathrm{CHOH})_{4}-\mathrm{CHO}+2 \mathrm{Ag}^{+}+\mathrm{H}_{2} \mathrm{O} \rightarrow \mathrm{CH}_{2} \mathrm{OH}-(\mathrm{CHOH})_{4}-\mathrm{COOH}+2 \mathrm{Ag}+2 \mathrm{H}^{+}$ 
broke into $\mathrm{Ag}^{+}$and $\mathrm{S}^{2-}$ ions following the equilibrium of reaction (4). Because of this, the content of silver sulfide in our product was reduced.

Subsequently, due to the coalesce of $\mathrm{H}^{+}$and $\mathrm{S}^{2-}$ ions generated from reactions (3) and (4), respectively, hydrogen sulfide $\left(\mathrm{H}_{2} \mathrm{~S}\right)$ was formed by following the reaction (5):

$2 \mathrm{H}^{+}+\mathrm{S}^{2-} \leftrightarrow \mathrm{H}_{2} \mathrm{~S}$

Being very sensitive to $\mathrm{S}^{2-}$, the silver was eroded by hydrogen sulfide, which is expressed by the reaction given below.

$\mathrm{O}_{2}+2 \mathrm{H}_{2} \mathrm{~S}+4 \mathrm{Ag} \rightarrow 2 \mathrm{Ag}_{2} \mathrm{~S}+2 \mathrm{H}_{2} \mathrm{O}$

Following the reaction (6), eroded silver was formed, and it released few $\mathrm{Ag}^{+}$ions. The reaction (6) was

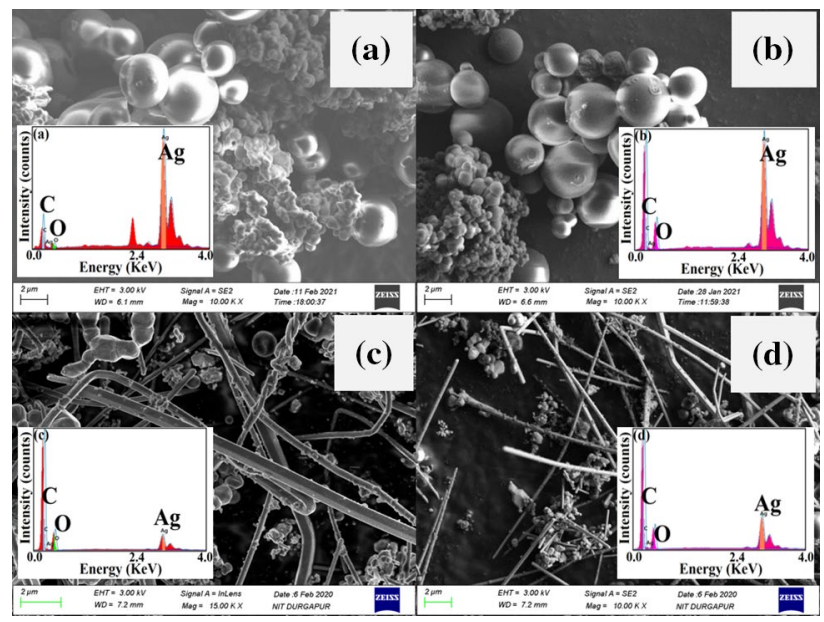

Fig. 2 FESEM image of a Ag/C-5, b Ag/C-10, c Ag/C-15, d Ag/C-20. Their corresponding EDX patterns are given in the inset of FESEM images controlled by silver sulfide, and this sluggish reaction is very helpful for the growth of 1D silver nanostructure. The silver sulfide of reaction (6) was reduced by glucose in our experiment, and the reaction stopped when the silver was layered by carbon. The reaction kinetics is given as:

$$
\begin{aligned}
& \mathrm{CH}_{2} \mathrm{OH}-(\mathrm{CHOH})_{4}-\mathrm{CHO}+\mathrm{Ag}_{2} \mathrm{~S}+\mathrm{H}_{2} \mathrm{O} \\
& \quad \rightarrow \mathrm{CH}_{2} \mathrm{OH}-(\mathrm{CHOH})_{4}-\mathrm{COOH}+2 \mathrm{Ag}+\mathrm{H}_{2} \mathrm{~S}
\end{aligned}
$$

Scheme 2: FESEM and EDX analysis

The morphology of the synthesized $\mathrm{Ag} / \mathrm{C}$ powders was explored by the FESEM image. Figure $2 a-d$ shows the FESEM images of all $\mathrm{Ag} / \mathrm{C}$ catalysts. Figure 2 specifies that $\mathrm{Ag} / \mathrm{C}-5$ was mostly contained of particles and few spherical structures. Ag/C-10 was mainly contained in core/shell spherical structures. The dark inner core and outer layer are observed due to the presence of carbon and silver. It is found that $\mathrm{Ag} / \mathrm{C}-15$ composes few $1 \mathrm{D}$ structures with a light sheath layer and dark inner core along the axis. It is an indication that the 1D structure started to form. In higher reaction time, the number of $1 \mathrm{D}$ structure to the number of particles ratio was increased and the $\mathrm{Ag} / \mathrm{C}-20$ was composed of mostly 1D structure with an almost uniform diameter. We could notice that the 1D nanostructures have previously been shielded by a glassy layer. This identified that the formation of nanocables was led with the carbonization of glucose in the hydrothermal synthesis method. In the case of larger reaction time, we observed that the number of irregular particles reduced in our samples, and the product was largely composed of rod-like or bar-like 1D structures. EDX has been analyzed to explore the purity and compositions of synthesized samples. The EDX patterns of all samples are shown in the inset of their corresponding FESEM images. These patterns showed that the prepared $\mathrm{Ag} / \mathrm{C}$ samples consist of carbon, oxygen, and silver. The silver content of $\mathrm{Ag} / \mathrm{C}-5, \mathrm{Ag} / \mathrm{C}-10, \mathrm{Ag} / \mathrm{C}-15$, and $\mathrm{Ag} / \mathrm{C}-20$ is $77.63,42.3,9.95$, and $18.5 \mathrm{wt} \%$, respectively.
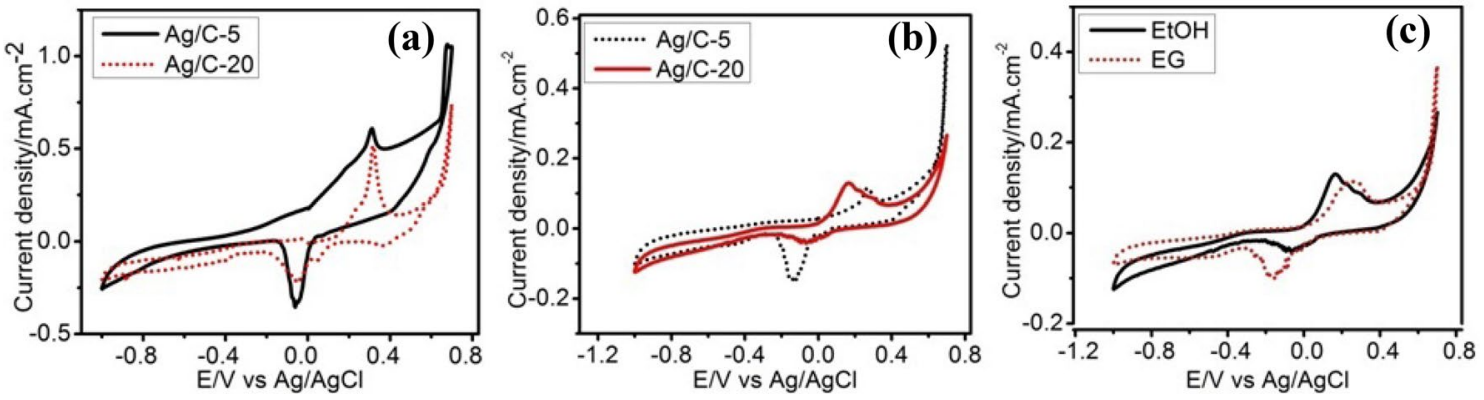

Fig. 3 a CV of $\mathrm{Ag} / \mathrm{C}-5$ and $\mathrm{Ag} / \mathrm{C}-20$ at $0.5 \mathrm{M} \mathrm{NaOH}$ at $100 \mathrm{mV} \mathrm{s}{ }^{-1}$ scan rate at $25^{\circ} \mathrm{C}, \mathbf{b} \mathrm{CV}$ of $\mathrm{Ag} / \mathrm{C}-5$ and $\mathrm{Ag} / \mathrm{C}-20$ at $0.5 \mathrm{M} \mathrm{NaOH}+1 \mathrm{M} \mathrm{EtOH}$ at $100 \mathrm{mV} \mathrm{s}^{-1}$ scan rate at $25^{\circ} \mathrm{C}, \mathrm{c} \mathrm{CV}$ of Ag/C-20 at $0.5 \mathrm{M} \mathrm{NaOH}+1 \mathrm{M} \mathrm{EtOH}$ and $0.5 \mathrm{M} \mathrm{NaOH}+1 \mathrm{M} \mathrm{EG}$ at $100 \mathrm{mV} \mathrm{s}^{-1}$ scan rate at $25^{\circ} \mathrm{C}$ 


\subsection{Electrocatalytic performances of $\mathrm{Ag} / \mathrm{C}$}

Firstly, we performed the cyclic voltammetry (CV) of our samples in $0.5 \mathrm{M} \mathrm{NaOH}$ solution at a scan rate of $100 \mathrm{mV} \mathrm{s}^{-1}$. Figure 3 a displays the typical redox peaks for $\mathrm{Ag} / \mathrm{C}-5$ and $\mathrm{Ag} / \mathrm{C}-20$, which were associated with the oxidation and reduction of $\mathrm{Ag}$, respectively. The oxidation peaks are due to the formation of silver oxide $\left(\mathrm{Ag}_{2} \mathrm{O}\right)$, and the reduction peaks are associated with the reduction of $\mathrm{Ag}_{2} \mathrm{O}$ to metallic silver [26, 27]. The Ag/C-5 sample has higher oxidation (forward) and reduction (backward) peak current than $\mathrm{Ag} / \mathrm{C}-20$ at almost the same potential vs. $\mathrm{Ag} / \mathrm{AgCl}$. Ag/C-5 has $0.092 \mathrm{~mA} \mathrm{~cm}^{-2}$ higher oxidation peak current and $2.44 \mathrm{mV}$ negative sweep in the forwarding peak position than that of $\mathrm{Ag} / \mathrm{C}-20$. The $\mathrm{CVs}$ of these catalysts in the presence of alcohol were studied to establish their tolerance as an electrocatalyst in energy devices [26]. To study the activity of these catalysts for alcohol oxidation in an alkaline medium, $\mathrm{CV}$ s were done in $0.5 \mathrm{M} \mathrm{NaOH}+1 \mathrm{M} \mathrm{EtOH}$ solution and $0.5 \mathrm{M} \mathrm{NaOH}+1 \mathrm{M} \mathrm{EG}$ solution. Figure $3 \mathrm{~b}$ shows the $\mathrm{CVs}$ of $\mathrm{Ag} / \mathrm{C}-5$ and $\mathrm{Ag} / \mathrm{C}-20$ in the presence of $\mathrm{EtOH}$. The curves do not show alcohol oxidation behavior, indicating that $\mathrm{Ag} / \mathrm{C}$ catalyst is not active for ethanol (EtOH) oxidation in alkaline media. At the same time, a blockage is observed of the peaks for the formation and reduction of silver oxide. This is the indication that ethanol is absorbed without oxidation [26]. The $\mathrm{Ag} / \mathrm{C}-20$ has shown a comparatively higher oxidation peak and $104.98 \mathrm{mV}$ negative sweeps in anodic peak in the presence of ethanol. The values of oxidation/forward current $\left(J_{f}\right)$, reduction/backward current $\left(J_{b}\right)$, and their peak positions vs. $\mathrm{Ag} / \mathrm{AgCl}$ for $\mathrm{Ag} / \mathrm{C}-5$ and $\mathrm{Ag} / \mathrm{C}-20$ catalysts from Fig. $3 \mathrm{a}, \mathrm{b}$ are presented in Table 1 . The feature is the same in the presence of ethylene glycol (EG); the $\mathrm{CV}$ of $\mathrm{Ag} / \mathrm{C}-20$ in the presence of ethylene glycol is shown in Fig. $3 \mathrm{C}$. It is clearly shown that $\mathrm{Ag} / \mathrm{C}-20$ has a lower anodic (forward) current in the presence of ethylene glycol than that of ethanol. The values of $\mathrm{J}_{\mathrm{f}}, \mathrm{J}_{\mathrm{b}}$ and their peak positions for the $\mathrm{Ag} / \mathrm{C}-20$ catalyst from Fig. $3 \mathrm{C}$ are presented in Table 2 . The forward-to-backward peak current ratio $\left(\mathrm{J}_{\mathrm{f}} / \mathrm{J}_{\mathrm{b}}\right)$ roughly indicates the tolerance of catalyst surface to poisoning species from carbonaceous intermediates; a higher value of this ratio indicates a higher tolerance [28-33].

The high $\mathrm{J}_{\mathrm{f}} / \mathrm{J}_{\mathrm{b}}$ values indicate the lower accumulation and effective removal of poisoning species on the electrode surface $[34,35]$. That ratio is 4.13 times higher for $\mathrm{Ag} / \mathrm{C}-20$ than that of $\mathrm{Ag} / \mathrm{C}-5$ in the presence of ethanol, which is a good agreement with the CV profile in Fig. 3b; $\mathrm{Ag} / \mathrm{C}-20$ has a better activity of alcohol tolerance. The $\mathrm{J}_{\mathrm{f}} /$ $J_{b}$ value for $\mathrm{Ag} / \mathrm{C}-20$ in the presence of ethylene glycol is 2.73 times lower than that in the presence of ethanol. This is a clear indication that the $\mathrm{Ag} / \mathrm{C}$ catalyst is more active for ethanol tolerance than that of ethylene glycol.

EIS is an important method to study electro-oxidation kinetics. It is a powerful tool to understand the properties of the interface of the modified electrode surfaces [36]. In

Table 1 Oxidation, reduction currents, and peak positions from Fig. 3a, b

\begin{tabular}{|c|c|c|c|c|c|c|c|c|c|}
\hline \multirow[t]{3}{*}{ Sample } & \multicolumn{9}{|l|}{ Electrolyte } \\
\hline & \multicolumn{4}{|l|}{$0.5 \mathrm{M} \mathrm{NaOH}$} & \multicolumn{5}{|c|}{$0.5 \mathrm{M} \mathrm{NaOH}+1 \mathrm{M} \mathrm{EtOH}$} \\
\hline & $\begin{array}{l}\text { Forward } \\
\text { current }_{f} \\
\left(\mathrm{~mA} \mathrm{~cm}^{-2}\right)\end{array}$ & $\begin{array}{l}\text { Forward peak } \\
\text { position }(\mathrm{mV})\end{array}$ & $\begin{array}{l}\text { Backward } \\
\text { current } J_{b}, \\
\left(\mathrm{~mA} \mathrm{~cm}^{-2}\right)\end{array}$ & $\begin{array}{l}\text { Backward } \\
\text { position }(\mathrm{mV})\end{array}$ & $\begin{array}{l}\text { Forward } \\
\text { current } J_{f} \\
\left(\mathrm{~mA} \mathrm{~cm}^{-2}\right)\end{array}$ & $\begin{array}{l}\text { Forward peak } \\
\text { position }(\mathrm{mV})\end{array}$ & $\begin{array}{l}\text { Backward } \\
\text { current } \mathrm{J}_{\mathrm{b}} \\
\left.(\mathrm{mA} \mathrm{cm})^{-2}\right)\end{array}$ & $\begin{array}{l}\text { Backward } \\
\text { position }(\mathrm{mV})\end{array}$ & $\left(J_{f} / J_{b}\right)$ \\
\hline \multirow[t]{2}{*}{$\mathrm{Ag} / \mathrm{C}-5$} & 0.608 & $\begin{array}{l}314.94(\mathrm{Ag} / \\
\mathrm{AgCl})\end{array}$ & -0.354 & $\begin{array}{c}-61.03(\mathrm{Ag} / \\
\mathrm{AgCl})\end{array}$ & 0.116 & $\begin{array}{l}268.55(\mathrm{Ag} / \\
\mathrm{AgCl})\end{array}$ & -0.153 & $\begin{array}{l}-131.83(\mathrm{Ag} / \\
\mathrm{AgCl})\end{array}$ & -0.75 \\
\hline & & 1261.84 (RHE) & & 885.87 (RHE) & & 1209.55 (RHE) & & 809.17 (RHE) & \\
\hline \multirow[t]{2}{*}{$\mathrm{Ag} / \mathrm{C}-20$} & 0.516 & $\begin{array}{l}317.38(\mathrm{Ag} / \\
\mathrm{AgCl})\end{array}$ & -0.218 & $\begin{array}{c}-56.15(\mathrm{Ag} / \\
\mathrm{AgCl})\end{array}$ & 0.129 & $\begin{array}{l}163.57(\mathrm{Ag} / \\
\mathrm{AgCl})\end{array}$ & -0.041 & $\begin{array}{c}-65.91(\mathrm{Ag} / \\
\mathrm{AgCl})\end{array}$ & -3.14 \\
\hline & & 1264.28 (RHE) & & 890.75 (RHE) & & 1104.57 (RHE) & & 875.09 (RHE) & \\
\hline
\end{tabular}

Table 2 Oxidation, reduction currents, and peak positions from Fig. $3 \mathrm{c}$

\begin{tabular}{|c|c|c|c|c|c|}
\hline \multirow[t]{3}{*}{ Sample } & \multicolumn{5}{|l|}{ Electrolyte } \\
\hline & \multicolumn{5}{|l|}{$0.5 \mathrm{M} \mathrm{NaOH}+1 \mathrm{M} \mathrm{EG}$} \\
\hline & $\begin{array}{l}\text { Forward current } \mathrm{J}_{\mathrm{f}} \\
\left(\mathrm{mA} \mathrm{cm}^{-2}\right)\end{array}$ & Forward peak position (mV) & $\begin{array}{l}\text { Backward current } J_{b} \\
\left(\mathrm{~mA} \mathrm{~cm}^{-2}\right)\end{array}$ & Backward position (mV) & $\left(J_{f} / J_{b}\right)$ \\
\hline \multirow[t]{2}{*}{$\mathrm{Ag} / \mathrm{C}-20$} & 0.115 & $249.02(\mathrm{Ag} / \mathrm{AgCl})$ & -0.100 & $-156.25(\mathrm{Ag} / \mathrm{AgCl})$ & -1.15 \\
\hline & & $1195.92(\mathrm{RHE})$ & & 790.65 (RHE) & \\
\hline
\end{tabular}


Fig. 4 a EIS at $0.5 \mathrm{M} \mathrm{NaOH}$ solution on $\mathrm{Ag} / \mathrm{C}-5$ and $\mathrm{Ag} / \mathrm{C}$ 20 modified electrodes, $\mathbf{b}$ EIS at $0.5 \mathrm{M} \mathrm{NaOH}+1 \mathrm{M} \mathrm{EtOH}$ on $\mathrm{Ag} / \mathrm{C}-5$ and $\mathrm{Ag} / \mathrm{C}-20$ modified electrode
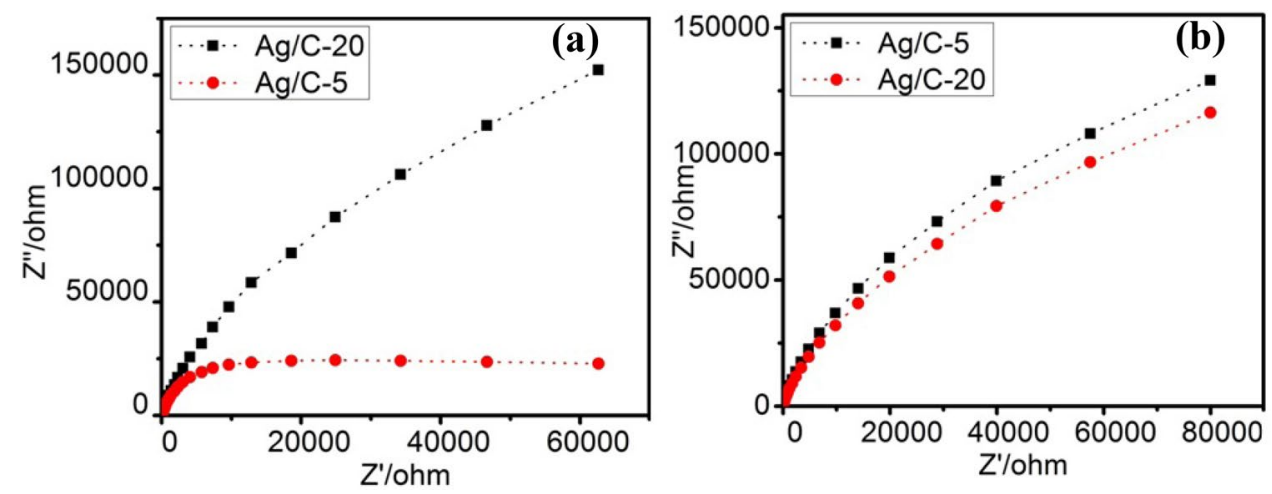

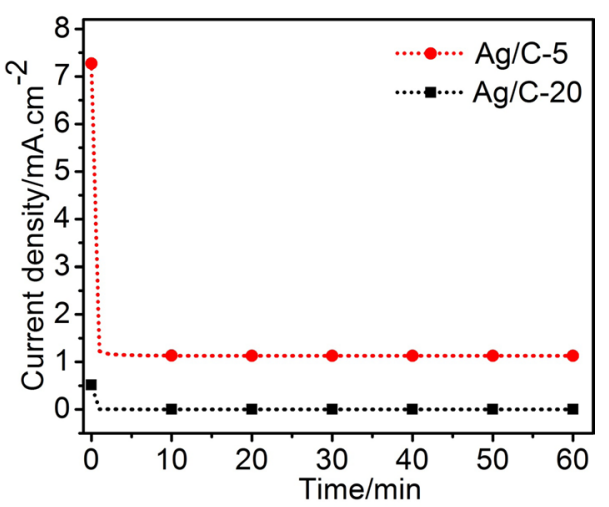

Fig. $5 \mathrm{CA}$ curves of $\mathrm{Ag} / \mathrm{C}-5$ and $\mathrm{Ag} / \mathrm{C}-20$ in $0.5 \mathrm{M} \mathrm{NaOH}$ solution at $0.3 \mathrm{~V}$

our work, we carried on ElS between $10^{5}$ and $0.1 \mathrm{~Hz}$ and at amplitude of $0.01 \mathrm{~V}$ for all $\mathrm{Ag} / \mathrm{C}$ catalysts at various electrolyte solutions. All the curves in our EIS profile display arclike shapes. The diameter of the arc shapes in the EIS profile is an important parameter for measuring the electron transfer resistance (Rct). The arc diameter is equal to $R c t$ [37]. The smaller diameter of the impedance arc indicates the lower value of $R c t$ for the electro-oxidation reaction that is the catalysts have good electron transfer kinetics and electrical conductivity for the electro-oxidation reaction, which is confirmable with good electrocatalytic activity [37]. Figure $4 \mathrm{a}, \mathrm{b}$ displays EIS for $\mathrm{Ag} / \mathrm{C}-5$ and $\mathrm{Ag} / \mathrm{C}-20$ at $0.5 \mathrm{M} \mathrm{NaOH}$ and $0.5 \mathrm{M} \mathrm{NaOH}+1 \mathrm{M} \mathrm{EtOH}$ solutions. In Fig. 4a, the arc diameter, i.e., Rct, is smaller and in Fig. $4 \mathrm{~b}$ that is higher for Ag/C-5 which is good agreement with the CVs profile in Fig. 3a, b, respectively.

The durability of electrocatalysts is an important thing for the electrochemical activity of those catalysts. Motivated from this, chronoamperometry (CA) for 1 hour was investigated to evaluate the stability of the catalysts. Figure 5 displays the $C A$ curves of the $\mathrm{Ag} / \mathrm{C}-5$ and $\mathrm{Ag} / \mathrm{C}-20$ catalysts in $0.5 \mathrm{M} \mathrm{NaOH}$ solution at $0.3 \mathrm{~V}$ (vs. $\mathrm{Ag} / \mathrm{AgCl}$ ). In the first phase, it is observed that the catalysts showed a rapid current decay because of the absorbance of species

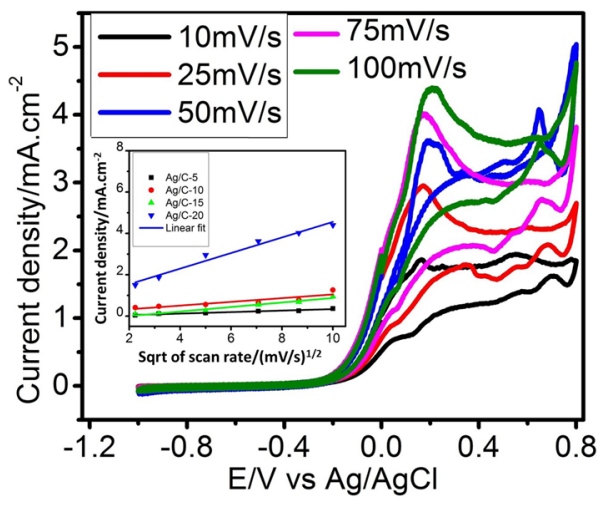

Fig. $6 \mathrm{CV}$ of $\mathrm{Ag} / \mathrm{C}-20$ at $0.5 \mathrm{M} \mathrm{NaOH}+0.01 \mathrm{M} \mathrm{NaBH}_{4}$ at different scan rates at $25^{\circ} \mathrm{C}$. Corresponding plot of maximum forward peak currents versus square root of scan rates for all $\mathrm{Ag} / \mathrm{C}$ catalysts are shown in inset

on the electrode diffusion layer, and after that, it followed constant current up to the complete study of 1 hour [38, 39]. The constant current with time signifies the stability of catalysts [34]. From this CA study, it is clear that $\mathrm{Ag} / \mathrm{C}-5$ has lower current decay than that of $\mathrm{Ag} / \mathrm{C}-20$ at $60 \mathrm{~min}$. That indicates in $0.5 \mathrm{M} \mathrm{NaOH}$ solution $\mathrm{Ag} / \mathrm{C}-5$ has higher durability than that of $\mathrm{Ag} / \mathrm{C}-20$, which is good assistance of $\mathrm{CV}$ and EIS profile in the same solution.

To understand the borohydride oxidation (BOR) kinetics of the $\mathrm{Ag} / \mathrm{C}$ electrode, we investigated the cyclic voltammetry of all $\mathrm{Ag} / \mathrm{C}$ electrodes in the presence of $\mathrm{NaBH}_{4}$ at different scan rates. The typical cyclic voltammetry of the $\mathrm{Ag} / \mathrm{C}-20$ electrode is shown in Fig. 6 with different scan rates in a $0.5 \mathrm{M} \mathrm{NaOH}+0.01 \mathrm{M} \mathrm{NaBH}_{4}$ solution. The electrocatalytic behavior for borohydride oxidation is complicated because of more than one oxidation peak. In forward scan, a large oxidation peak is observed at around $0.2 \mathrm{~V}$ (vs $\mathrm{Ag} / \mathrm{AgCl}$ ), followed by another anodic peak having a broad hump but a small height at around 0.6V (vs Ag/AgCl). During the backward scan, we observed a well-defined anodic spike at around $0.65 \mathrm{~V}$ (vs Ag/AgCl). The first peak at around $0.2 \mathrm{~V}$ (vs Ag/AgCl) is due to $\mathrm{H}_{2}$ oxidation, which is produced 


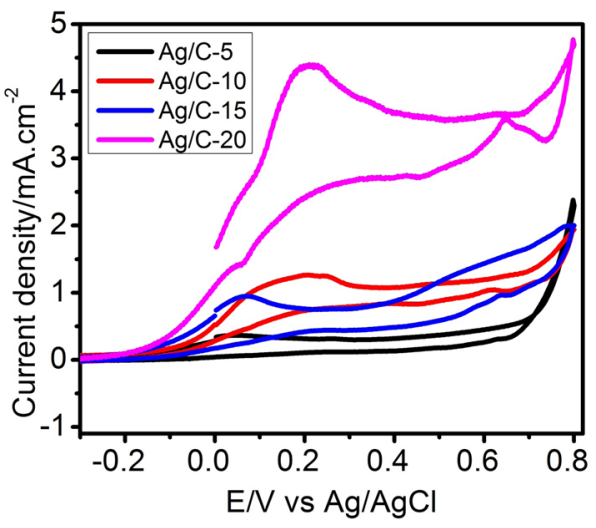

Fig. $7 \mathrm{CV}$ of all $\mathrm{Ag} / \mathrm{C}$ at $0.5 \mathrm{M} \mathrm{NaOH}+0.01 \mathrm{M} \mathrm{NaBH}_{4}$ at $100 \mathrm{mV} . \mathrm{s}^{-1}$ scan rate at $25^{\circ} \mathrm{C}$

by $\mathrm{BH}_{4}$ hydrolysis, and the second peak at around $0.6 \mathrm{~V}$ (vs $\mathrm{Ag} / \mathrm{AgCl}$ ) in the forward scan is observed because of the direct $\mathrm{BH}_{4}{ }^{-}$oxidation on $\mathrm{Ag} / \mathrm{C}$ electrocatalyst with $\mathrm{BO}_{2}$ and hydrogen as products [8].

$\mathrm{BH}_{4}^{-}+\mathrm{H}_{2} \mathrm{O} \rightarrow \mathrm{BH}_{3} \mathrm{OH}+\mathrm{H}_{2}$

$\mathrm{BH}_{3} \mathrm{OH}+\mathrm{H}_{2} \mathrm{O} \rightarrow \mathrm{BO}_{2}^{-}+3 \mathrm{H}_{2}$

The current is still in increasing fashion after direct $\mathrm{BH}_{4}{ }^{-}$oxidation with the formation of silver oxide, which is the direct borohydride oxidation that mainly happened upon multilayered silver oxide [40].

$2 \mathrm{Ag}+2 \mathrm{OH}^{-} \rightarrow \mathrm{Ag}_{2} \mathrm{O}+\mathrm{H}_{2} \mathrm{O}+2 \mathrm{e}^{-}$

$\mathrm{Ag}_{2} \mathrm{O}+\mathrm{BH}_{4}^{-}+6 \mathrm{OH}^{-} \rightarrow 2 \mathrm{Ag}+\mathrm{BO}_{2}^{-}+5 \mathrm{H}_{2} \mathrm{O}+6 e^{-}$

The peak at around $0.65 \mathrm{~V}$ (vs $\mathrm{Ag} / \mathrm{AgCl}$ ) in a backward scan corresponds to the oxidation of $\mathrm{BH}_{3} \mathrm{OH}^{-}$or the surface-adsorbed intermediates of $\mathrm{BH}_{3} \mathrm{OH}^{-}$on the catalyst surface, which is partially oxidized $[1,2]$.

$\mathrm{BH}_{3} \mathrm{OH}+3 \mathrm{OH}^{-} \rightarrow \mathrm{BO}_{2}^{-}+\frac{3}{2} \mathrm{H}_{2}+2 \mathrm{H}_{2} \mathrm{O}+3 e^{-}$

With the increase of scan rates of cyclic voltammetry (Fig. 6), it is clear that the maximum oxidation peak potentials in the forwarding scan showed a positive shift followed by the increment in the current. This positive shift of maximum forward peak potentials with the scan rates is a feature of irreversible systems [41-43]. Figure 7 displays the $\mathrm{CV}$ profile of all the synthesized $\mathrm{Ag} / \mathrm{C}$ catalysts in the same solution. Among all the catalysts, $\mathrm{Ag} / \mathrm{C}-20$ showed the maximum forward peak current of $4.38 \mathrm{~mA} . \mathrm{cm}^{-2}$ at $202 \mathrm{mV}$ (vs $\mathrm{Ag} / \mathrm{AgCl}$ ) potential. The obtained value of
Table 3 Forward peak currents and corresponding peak potentials from Fig. 7

\begin{tabular}{lll}
\hline Electrocatalyst & $\begin{array}{l}\text { Forward peak current } \\
\left(\mathrm{mA} \mathrm{cm}^{-2}\right)\end{array}$ & $\begin{array}{l}\text { Forward peak } \\
\text { potential }(\mathrm{mV})\end{array}$ \\
\hline $\mathrm{Ag} / \mathrm{C}-5$ & 0.36 & $\begin{array}{l}39(\mathrm{Ag} / \mathrm{AgCl}) \\
1021.3(\mathrm{RHE})\end{array}$ \\
$\mathrm{Ag} / \mathrm{C}-10$ & 1.26 & $207(\mathrm{Ag} / \mathrm{AgCl})$ \\
& & $1189.3(\mathrm{RHE})$ \\
$\mathrm{Ag} / \mathrm{C}-15$ & 0.94 & $68(\mathrm{Ag} / \mathrm{AgCl})$ \\
& & $1050.3(\mathrm{RHE})$ \\
$\mathrm{Ag} / \mathrm{C}-20$ & 4.38 & $202(\mathrm{Ag} / \mathrm{AgCl})$ \\
& & $1184.3(\mathrm{RHE})$ \\
\hline
\end{tabular}

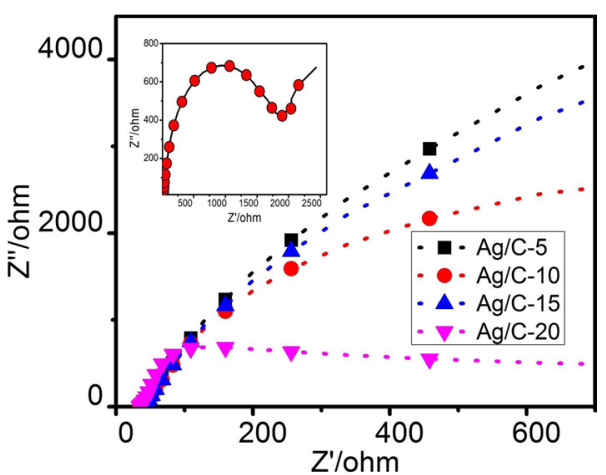

Fig. 8 ElS at $0.5 \mathrm{M} \mathrm{NaOH}+0.01 \mathrm{M} \mathrm{NaBH}_{4}$ solution on all $\mathrm{Ag} / \mathrm{C}$ modified electrodes. Inset shows the EIS profile of $\mathrm{Ag} / \mathrm{C}-20$ up to very low frequency

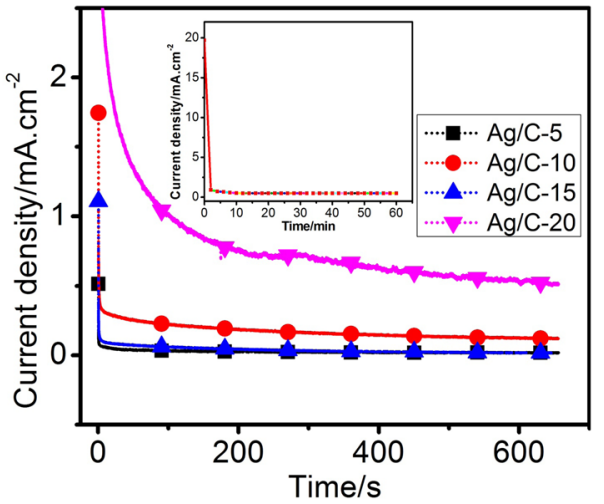

Fig. 9 CA curves of all Ag/C catalysts in $0.5 \mathrm{M} \mathrm{NaOH}+0.01 \mathrm{M} \mathrm{NaBH}_{4}$ solution at $0.2 \mathrm{~V}$. Inset shows the chronoamperometry profile of $\mathrm{Ag} / \mathrm{C}-20$ up to $1 \mathrm{~h}$

forwarding peak current is higher than that reported by Stosevski et al for $\mathrm{Ag} / \mathrm{C}$ catalysts [1] in $2 \mathrm{M} \mathrm{NaOH}+0.03 \mathrm{M}$ $\mathrm{NaBH}_{4}$ electrolyte solution at $50 \mathrm{mV} \cdot \mathrm{s}^{-1}$ scan rate. The value of maximum forward currents and corresponding potentials is listed in Table 3. Inset of Fig. 6 displays the graph of 
forwarding peak current versus square root of scan rate of all active catalysts. We observed an almost linear relationship between the square root of scan rate and forward peak current. These results indicate that the borohydride oxidation on $\mathrm{Ag} / \mathrm{C}$ modified electrode surface is probably the diffusion-controlled process; the largest slope value of these graphs suggested the good electro-oxidation and electron transfer kinetics of $\mathrm{Ag} / \mathrm{C}-20[43,44]$.

Figures 8 and 9 are the EIS and chronoamperometry representation at $0.5 \mathrm{M} \mathrm{NaOH}+0.01 \mathrm{M} \mathrm{NaBH}_{4}$ solution at all $\mathrm{Ag} / \mathrm{C}$ modified electrodes. The high-frequency portion of the EIS profile is a semicircular impedance arc, the diameter of which corresponds to faradic electron transfer resistance at the electrolyte-electrode interface during borohydride oxidation. The EIS profile showed the lowest arc diameter for $\mathrm{Ag} / \mathrm{C}-20$, confirming its highest electrochemical kinetics for borohydride oxidation. In the inset of the EIS curve, the low-frequency part of the Ag/C-20 electrode shows an almost linear nature. The semicircular impedance arc and the linear portion of this EIS profile confirm the charge-transfer-limited process and diffusionlimited process, respectively [30]. Chronoamperometry of all $\mathrm{Ag} / \mathrm{C}$ catalysts has done in $0.5 \mathrm{M} \mathrm{NaOH}+0.01 \mathrm{M} \mathrm{NaBH}_{4}$ solution at $0.2 \mathrm{~V}$ to verify the stability of the electrodes in that electrolyte. We observed a rapid current decay initially in 1 second followed by a fixed value of current till the complete study. The rapid current decay in the first phase is due to the absorbance of species on the electrode diffusion layer. The constant value of current with time indicates that $\mathrm{Ag} / \mathrm{C}$ is a stable candidate as an electrocatalyst for borohydride oxidation in alkaline medium. From this chronoamperometry study, it is confirmed that $\mathrm{Ag} / \mathrm{C}-20$ has the lowest current decay than other $\mathrm{Ag} / \mathrm{C}$ catalysts indicating its better electrochemical kinetics for borohydride oxidation. Inset of chronoamperometry profile shows the good stability of $\mathrm{Ag} / \mathrm{C}-20$ catalyst up to 1 hour.

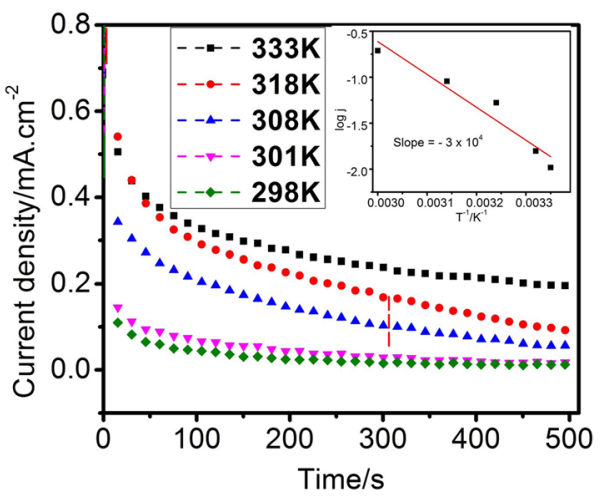

Fig. $10 \mathrm{CV}$ curves of $\mathrm{Ag} / \mathrm{C}-20$ at different temperatures at $0.2 \mathrm{~V}$ in $0.5 \mathrm{M} \mathrm{NaOH}+0.01 \mathrm{M} \mathrm{NaBH}_{4}$. Inset shows the corresponding plot of $\log \mathrm{j}$ vs $1 / \mathrm{T}$
The apparent activation energy (Eapp) for the borohydride oxidation reaction at $\mathrm{Ag} / \mathrm{C}-20$ electrodes in $0.5 \mathrm{M}$ $\mathrm{NaOH}+0.01 \mathrm{M} \mathrm{NaBH}_{4}$ electrolyte solution was measured from CA data (Fig. 10) in the $25-60^{\circ} \mathrm{C}$ temperatures range, using the Arrhenius equation (Eq. 13):

$\frac{\partial \log j}{\partial T}=-\frac{E_{\mathrm{app}}}{R T^{2}}$

where $j$ is the current density $\left(\mathrm{mA} \mathrm{cm}^{-2}\right), \mathrm{T}$ is the thermodynamic temperature $(\mathrm{K})$ and $R$ is the molar gas constant $\left(8.314 \mathrm{~J} \mathrm{~mol}^{-1} \mathrm{~K}^{-1}\right)$. The $\mathrm{CA}$ data at different temperatures indicate that the electrocatalytic performance of $\mathrm{NaBH}_{4}$ was improved by increasing the temperature, which proves that electrode reaction dynamics become faster at higher temperatures. Inset of Fig. 10 presents the Arrhenius plot of log $j$ versus $1 / T$. From the slope of this plot and using the Arrhenius equation (Eq. 13), the value of $E_{\mathrm{app}}$ of $\mathrm{Ag} / \mathrm{C}-20$ for BOR was estimated as $57.2 \mathrm{~kJ} \mathrm{~mol}^{-1}$, which is higher in comparison with previous reports. The value of Eapp for borohydride oxidation reaction at several electrocatalysts, such as $\mathrm{CoBi}, \mathrm{Pt} / \mathrm{C}, \mathrm{Pt}_{0.75} \mathrm{Ni}_{0.25}$, and $\mathrm{Pt}_{0.75} \mathrm{Co}_{0.25}$, is $36.774,34.3,20.2$, and $25.3 \mathrm{~kJ} \mathrm{~mol}^{-1}$, respectively $[4,45]$. For $\mathrm{Ag}$ electrode, the already reported vale is $35 \mathrm{~kJ} \mathrm{~mol}^{-1}$ [1].

Cottrell equation was used to calculate exchanged electron number $(\mathrm{n})$ during borohydride electro-oxidation of $\mathrm{Ag} / \mathrm{C}-20$ catalyst as given below:

$j=\frac{n F C(D)^{1 / 2}}{(\pi t)^{1 / 2}}$.

where $\mathrm{F}$ is the Faraday constant $\left(96485 \mathrm{C} \mathrm{mol}^{-1}\right), \mathrm{C}$ is the $\mathrm{BH}_{4}{ }^{-}$concentration and $\mathrm{D}$ is the diffusion coefficient. Wang and co-workers [46] reported values of $D$ for $\mathrm{BH}_{4}{ }^{-}$oxidation at different temperatures in different concentrations of $\mathrm{NaOH}$, assuming that $D$ does not depend on $\mathrm{BH}_{4}{ }^{-}$concentration. Using the value of $F, C$, and from the slope (slope value $=5.229$ ) of $j$ versus $t^{-1 / 2}$ plots, $n$ value for $\mathrm{BH}_{4}^{-}$electro-oxidation at $\mathrm{Ag} / \mathrm{C}-20$ electrode in $0.5 \mathrm{M}$ $\mathrm{NaOH}+0.01 \mathrm{M} \mathrm{NaBH}_{4}$ at $30^{\circ} \mathrm{C}$ was found to be 2.27 , which is comparable to the reported values for $\mathrm{BOR}$ at $\mathrm{Pt}_{0.4} \mathrm{Dy}_{0.6}$ and $\mathrm{Pt}_{0.5} \mathrm{Dy}_{0.5}$ electrodes ( 2.5 and 2.4 , respectively) at $25^{\circ} \mathrm{C}$ [2]. Value of exchanged electrons lower than 8 indicates partial anodic oxidation of $\mathrm{BH}_{4}{ }^{-}$, with loss of available electrons due to $\mathrm{BH}_{4}^{-}$hydrolysis.

To study the effect of $\mathrm{NaBH}_{4}$ concentration on electrocatalytic performance of $\mathrm{Ag} / \mathrm{C}$ catalyst for borohydride oxidation, $\mathrm{CV}$ in different concentrations of $\mathrm{NaBH}_{4}$ $(0.005 \mathrm{M}, 0.01 \mathrm{M}, 0.015 \mathrm{M}, 0.02 \mathrm{M}, 0.025 \mathrm{M}$ and $0.03 \mathrm{M})$ was investigated at $\mathrm{Ag} / \mathrm{C}-20$ electrode. Figure 11 displays the $\mathrm{CV}$ profile of $\mathrm{Ag} / \mathrm{C}-20$ in different concentrations of $\mathrm{NaBH}_{4}$. It was clear from the $\mathrm{CV}$ profile that increment of $\mathrm{NaBH}_{4}$ concentration resulted in the significant enhancement 


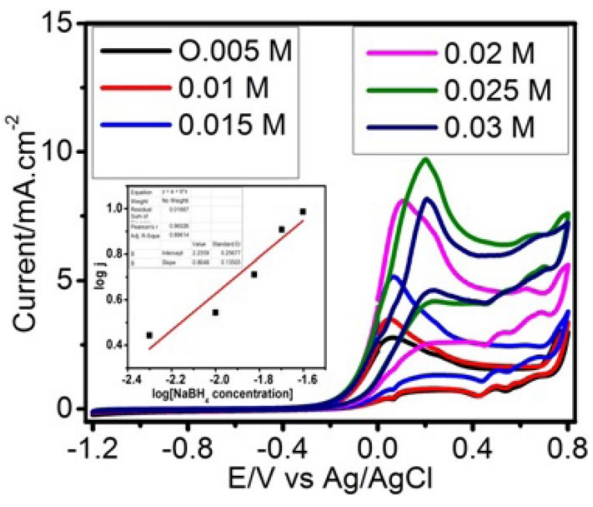

Fig. $11 \mathrm{CV}$ of $\mathrm{Ag} / \mathrm{C}-20$ in $0.5 \mathrm{M} \mathrm{NaOH}+\mathrm{x} \mathrm{M} \mathrm{NaBH}$ at $70 \mathrm{mV}^{-1} \mathrm{~s}^{-1}$ scan rate and $25{ }^{\circ} \mathrm{C}$ temperature. Inset shows the corresponding plot of $\log \mathrm{j}$ vs $\log \left[\mathrm{NaBH}_{4}\right.$ concentration]

of forwarding current densities, indicating a strong electrocatalytic property of $\mathrm{Ag} / \mathrm{C}$ nanobars toward borohydride electro-oxidation. The forward current densities and corresponding peak positions are given in Table 4. We observed a remarkable enhancement of current up to $0.025 \mathrm{M}$ increment of $\mathrm{NaBH}_{4}$. But a decrease of current for further increase of $\mathrm{NaBH}_{4}(0.03 \mathrm{M})$ was observed. This is because of the continuous consumption of $\mathrm{NaBH}_{4}$ on the electrode surface at a very high concentration of $\mathrm{NaBH}_{4}$ after $0.025 \mathrm{M}$. That can perturb the electrochemical kinetics of investigated electrode. Also, we noticed a positive shift of peak potentials at higher $\mathrm{NaBH}_{4}$ concentration.

To determine the order of reaction, we used the following equation [40]:

$i=z C^{\beta}$

where $z$ is a constant, $i$ and $C$ are the peak current and $\mathrm{NaBH}_{4}$ concentration, respectively, and $\beta$ is the order of the reaction. The slope value of $\log j$ vs $\log \left[\mathrm{NaBH}_{4}\right.$ concentration] obtained from Fig. 11 defines the order of the reaction. The value of this slope of this plot is 0.80 , which indicates that the borohydride oxidation in the $\mathrm{Ag} / \mathrm{C}$ electrode is a first-order reaction. Borohydride electro-oxidation in different materials like PtDy was also reported to be first order [2].

\subsection{Conclusion}

$\mathrm{Ag} / \mathrm{C}$ nanostructures were synthesized hydrothermally in different reaction times of $5 \mathrm{~h}, 10 \mathrm{~h}, 15 \mathrm{~h}$, and $20 \mathrm{~h}$ using glucose as a reducing agent and carbon source. Cyclic voltammetry for $\mathrm{Ag} / \mathrm{C}$ was studied in several electrolytes. Ag/C-5 showed better electrochemical activity in alkaline solution than $\mathrm{Ag} / \mathrm{C}-20$, but it has less alcohol tolerance than that of $A g / C-20$, which suggests that $A g / C$ 1D nanostructure has a comparably higher tolerance of poisonous species. All $\mathrm{Ag} / \mathrm{C}$ catalysts were investigated for borohydride electro-oxidation reaction in an alkaline medium for prospective application as an electrocatalyst in alkaline direct borohydride fuel cell (DBFC). All Ag/C catalysts exhibited sharp anodic current for borohydride electro-oxidation. Borohydride oxidation reaction at carbon-supported silver electrocatalysts is accepted to be happened due to the generation of surface oxides of silver. Chronoamperometry study displayed constant current after a rapid decay in the $1^{\text {st }}$ second, which implies the stability of $\mathrm{Ag} / \mathrm{C}$ as a potential electrocatalyst. $\mathrm{Ag} / \mathrm{C}$ nanobars showed better performance as an electrocatalyst for BOR in an alkaline medium than other synthesized $\mathrm{Ag} / \mathrm{C}$. Thus, being affordable and stable carbon-supported silver nanobar can be used as a propitious anode in the borohydride fuel cell.
Table 4 Forward peak current densities and corresponding peak potentials from Fig. 11

\begin{tabular}{|c|c|c|c|}
\hline Electrolyte solution & $\begin{array}{l}\text { NaBH4 concen- } \\
\text { trations }(x \mathrm{M})\end{array}$ & $\begin{array}{l}\text { Forward peak cur- } \\
\text { rent }\left(\mathrm{mA} \mathrm{cm}^{-2}\right)\end{array}$ & Forward peak potential (V) \\
\hline \multirow[t]{6}{*}{$\begin{array}{c}0.5 \mathrm{M} \mathrm{NaOH}+x \mathrm{M} \mathrm{NaBH} 4(x=0.005 \\
0.01,0.015,0.02,0.025,0.03)\end{array}$} & 0.005 & 2.777 & $\begin{array}{l}0.063(\mathrm{Ag} / \mathrm{AgCl}) \\
1.045(\mathrm{RHE}))\end{array}$ \\
\hline & 0.010 & 3.495 & $\begin{array}{l}0.051(\mathrm{Ag} / \mathrm{AgCl}) \\
1.033(\mathrm{RHE})\end{array}$ \\
\hline & 0.015 & 5.152 & $\begin{array}{l}0.065(\mathrm{Ag} / \mathrm{AgCl}) \\
1.047(\mathrm{RHE})\end{array}$ \\
\hline & 0.020 & 8.085 & $\begin{array}{l}0.109(\mathrm{Ag} / \mathrm{AgCl}) \\
1.085(\mathrm{RHE})\end{array}$ \\
\hline & 0.025 & 9.705 & $\begin{array}{l}0.202(\mathrm{Ag} / \mathrm{AgCl}) \\
1.178(\mathrm{RHE})\end{array}$ \\
\hline & $0 . .030$ & 8.160 & $\begin{array}{l}0.205(\mathrm{Ag} / \mathrm{AgCl}) \\
1.181(\mathrm{RHE})\end{array}$ \\
\hline
\end{tabular}


Acknowledgment The authors like to thank the Department of Science and Technology (DST), Govt of India, for providing financial assistance through the project (EMR/2016/004926). Santanu Dey also acknowledges the Department of Physics, Sidho-Kanho-Birsha University, Purulia, for providing their instrumental facilities.

\section{Declaration}

Conflict of interest There is no conflict of interest.

Open Access This article is licensed under a Creative Commons Attribution 4.0 International License, which permits use, sharing, adaptation, distribution and reproduction in any medium or format, as long as you give appropriate credit to the original author(s) and the source, provide a link to the Creative Commons licence, and indicate if changes were made. The images or other third party material in this article are included in the article's Creative Commons licence, unless indicated otherwise in a credit line to the material. If material is not included in the article's Creative Commons licence and your intended use is not permitted by statutory regulation or exceeds the permitted use, you will need to obtain permission directly from the copyright holder. To view a copy of this licence, visit http://creativecommons. org/licenses/by/4.0/.

\section{References}

1. Stoševski I, Krstić J, Milikić J, Šljukić B, Kačarević-Popović Z, Mentus S, Miljanić S (2016) Radiolitically synthesized nano Ag/C catalysts for oxygen reduction and borohydride oxidation reactions in alkaline media, for potential applications in fuel cells. Energy 101:79-90. https://doi.org/10.1016/j.energy.2016.02.003

2. Šljukić B, Milikić J, Santos DM, Sequeira CAC, Macciò D, Saccone A (2014) Electrocatalytic performance of Pt-Dy alloys for direct borohydride fuel cells. J Power Sources 272:335-343. https:// doi.org/10.1016/j.jpowsour.2014.08.080

3. Šljukić B, Santos DM, Sequeira CAC, Banks CE (2013) Analytical monitoring of sodium borohydride. Anal methods 5(4):829-839. https://doi.org/10.1039/C2AY26077H

4. Šljukić B, Milikić J, Santos DMF, Sequeira CAC (2013) Carbonsupported $\mathrm{Pt}_{0.75} \mathrm{M}_{0.25}(\mathrm{M}=\mathrm{Ni}$ or $\mathrm{Co}$ ) electrocatalysts for borohydride oxidation. Electrochim Acta 107:577-583. https://doi. org/10.1016/j.electacta.2013.06.040

5. Li J, Hong X, Wang Y, Luo Y, Huang P, Li B, Zhang K, Zou Y, Sun $L$, Xu F, Rosei F (2020) Encapsulated cobalt nanoparticles as a recoverable catalyst for the hydrolysis of sodium borohydride. Energy Storage Mater 27:187-197. https://doi.org/10.1016/j. ensm.2020.01.011

6. Feng RX, Dong H, Wang YD, Ai XP, Cao YL, Yang HX (2005) A simple and high efficient direct borohydride fuel cell with $\mathrm{MnO}_{2}$-catalyzed cathode. Electrochem Commun 7(4):449-452. https://doi.org/10.1016/j.elecom.2005.02.023

7. Peled E, Livshits V, Duvdevani T (2002) High-power direct ethylene glycol fuel cell (DEGFC) based on nanoporous proton-conducting membrane (NP-PCM). J Power Sources 106(1-2):245248. https://doi.org/10.1016/S0378-7753(01)01028-X

8. Ma J, Sahai Y, Buchheit RG (2010) Direct borohydride fuel cell using $\mathrm{Ni}$-based composite anodes. J Power Sources 195(15):4709-4713. https://doi.org/10.1016/j.jpowsour.2010. 02.034

9. Yi L, Wei W, Zhao C, Yang C, Tian L, Liu J, Wang X (2015) Electrochemical oxidation of sodium borohydride on carbonsupported Pt-Zn nanoparticle bimetallic catalyst and its implications to direct borohydride-hydrogen peroxide fuel cell.
Electrochim Acta 158:209-218. https://doi.org/10.1016/j.elect acta.2015.01.111

10. Oh TH, Jang B, Kwon S (2014) Performance evaluation of direct borohydride-hydrogen peroxide fuel cells with electrocatalysts supported on multiwalled carbon nanotubes. Energy 76:911919. https://doi.org/10.1016/j.energy.2014.09.002

11. Oh TH, Jang B, Kwon S (2015) Estimating the energy density of direct borohydride-hydrogen peroxide fuel cell systems for air-independent propulsion applications. Energy 90:980-986. https://doi.org/10.1016/j.energy.2015.08.002

12. San FGB, Okur O, Karadağ Cl, Isik-Gulsac I, Okumuş E (2014) Evaluation of operating conditions on DBFC (direct borohydride fuel cell) performance with PtRu anode catalyst by response surface method. Energy 71:160-169. https://doi.org/10.1016/j.energy. 2014.04.037

13. Spendelow JS, Wieckowski A (2007) Electrocatalysis of oxygen reduction and small alcohol oxidation in alkaline media. Phys Chem Chem Phys 9(21):2654-2675. https://doi.org/10.1039/ B703315J

14. Riveros G, Green S, Cortes A, Gomez H, Marotti RE, Dalchiele EA (2006) Silver nanowire arrays electrochemically grown into nanoporous anodic alumina templates. Nanotechnology 17(2):561. https://doi.org/10.1088/0957-4484/17/2/037

15. Behrens S, Wu J, Habicht W, Unger E (2004) Silver nanoparticle and nanowire formation by microtubule templates. Chem Mater 16(16):3085-3090. https://doi.org/10.1021/cm049462s

16. Sun XM, Li YD (2005) Cylindrical silver nanowires: preparation, structure, and optical properties. Adv Mater 17(21):2626-2630. https://doi.org/10.1002/adma.200500957

17. Sun Y, Yin Y, Mayers BT, Herricks T, Xia Y (2002) Uniform silver nanowires synthesis by reducing $\mathrm{AgNO}_{3}$ with ethylene glycol in the presence of seeds and poly(vinylpyrrolidone). Chem Mater 14(11):4736-4745. https://doi.org/10.1021/cm020587b

18. Wang Z, Liu J, Chen X, Wan J, Qian Y (2005) A simple hydrothermal route to large-scale synthesis of uniform silver nanowires. Chem Euro J 11(1):160-163. https://doi.org/10.1002/chem. 200400705

19. Wang W, Xiong S, Chen L, Xi B, Zhou H, Zhang Z (2006) Formation of flexible $\mathrm{Ag} / \mathrm{C}$ coaxial nano cables through a novel solution process. Cryst Growth Des 6(11):2422-2426. https://doi.org/ $10.1021 / \mathrm{cg} 060068 \mathrm{~b}$

20. Fang Z, Tang K, Lei S, Li T (2006) CTAB-assisted hydrothermal synthesis of Ag/C nanostructures. Nanotechnology 17(12):3008. https://doi.org/10.1088/0957-4484/17/12/032

21. Yu SH, Cui XJ, Li LL, Li K, Yu B, Antonietti M, Cölfen H (2004) From starch to metal/carbon hybrid nanostructures: hydrothermal metal-catalyzed carbonization. Adv Mater 16(18):1636-1640. https://doi.org/10.1002/adma.200400522

22. Jin M, Kuang Q, Jiang Z, Xu T, Xie Z, Zheng L (2008) Direct synthesis of silver/polymer/carbon nanocables via a simple hydrothermal route. J Solid State Chem 181(9):2359-2363. https://doi. org/10.1016/j.jssc.2008.05.034

23. Mu J, Liu Y, Wang H, Ye J, Wen X, Gu L, Xie YT (2012) Surfactantfree hydrothermal synthesis of $\mathrm{Ag} / \mathrm{C}$ nanocables. Mater Exp 2(2):130-136. https://doi.org/10.1166/mex.2012.1067

24. Chen L, Ma D, Li X, Bao X (2006) Silver catalyst ssupported over activated carbons for the selective oxidation of $\mathrm{CO}$ in excess hydrogen: effects of different treatments on the supports. Catal Lett 111(3-4):133-139. https://doi.org/10.1007/ s10562-006-0139-2

25. Vinodh R, Sangeetha D (2012) Carbon supported silver (Ag/C) electrocatalysts for alkaline membrane fuel cells. J Mater Sci 47(2):852-859. https://doi.org/10.1007/s10853-011-5863-3

26. Hernández-Rodríguez MA, Goya $\mathrm{MC}$, Arévalo $\mathrm{MC}$, Rodríguez JL, Pastor E (2016) Carbon supported Ag and Ag-Co catalysts tolerant to methanol and ethanol for the oxygen reduction reaction 
in alkaline media. Int J Hydrogen Eng 41(43):19789-19798. https://doi.org/10.1016/j.ijhydene.2016.07.188

27. Chen SL, Wu BL, Cha CS (1996) Application of time-resolved EQCM to the study of the mechanism of silver (I) oxide formation on a polycrystalline silver electrode in alkaline solution. J Electroanal Chem 416(1-2):53-59. https://doi.org/10.1016/ S0022-0728(96)04719-5

28. Xing XL, Zhao YF, Li H, Wang CT, Li QX, Cai WB (2018) Highperformance $\mathrm{Ag}$ rich $\mathrm{Pd}-\mathrm{Ag}$ bimetallic electrocatalyst for ethylene glycol oxidation in alkaline media. J Electrochem Soc 165(15):3259-3265. https://doi.org/10.1149/2.0311815jes

29. Feng YY, Liu ZH, Kong WQ, Yin QY, Du LX (2014) Promotion of palladium catalysis by silver for ethanol electro-oxidation in alkaline electrolyte. Int J Hydrogen Eng 39(6):2497-2504. https:// doi.org/10.1016/j.ijhydene.2013.12.004

30. Xi P, Cao Y, Yang F, Ma C, Chen F, Yu S, Wang S, Zeng Z, Zhang $X$ (2013) Facile synthesis of Pd-based bimetallic nanocrystals and their application as catalysts for the methanol oxidation reaction. Nanoscale 5(13):6124-6130. https://doi.org/10.1039/ C3NR00912B

31. Li Y, Gao W, Ci L, Wang C, Ajayan PM (2010) Catalytic performance of Pt nanoparticles on reduced graphene oxide for methanol electro-oxidation. Carbon 48(4):1124-1130. https:// doi.org/10.1016/j.carbon.2009.11.034

32. Zhu LD, Zhao TS, Xu JB, Liang ZX (2009) Preparation and characterization of carbon-supported sub-monolayer palladium decorated gold nanoparticles for the electro-oxidation of ethanol in alkaline media. J Power Sources 187(1):80-84. https://doi.org/ 10.1016/j.jpowsour.2008.10.089

33. Su L, Jia W, Schempf A, Ding Y, Lei Y (2009) Free-standing palladium/polyamide 6 nanofibers for electrooxidation of alcohols in alkaline medium. J Phys Chem C 113(36):16174-16180. https:// doi.org/10.1021/jp905606s

34. Safavi A, Kazemi H, Momeni S, Tohidi M, Mehrin PK (2013) Facile electrocatalytic oxidation of ethanol using $\mathrm{Ag} / \mathrm{Pd}$ nanoalloys modified carbon ionic liquid electrode. Int J Hydrogen Eng 38(8):3380-3386. https://doi.org/10.1016/j.ijhydene.2012.12. 040

35. He X, Hu C (2011) Building three-dimensional Pt catalysts on $\mathrm{TiO}_{2}$ nanorod arrays for effective ethanol electrooxidation. J Power Sources 196(6):3119-3123. https://doi.org/10.1016/j. jpowsour.2010.12.001

36. Zhang K, Xu H, Yan B, Wang J, Du Y, Liu Q (2018) Superior ethylene glycol oxidation electrocatalysis enabled by hollow $\mathrm{PdNi}$ nanospheres. Electrochim Acta 268:383-391. https://doi.org/10. 1016/j.electacta.2018.02.123
37. Sevilla M, Lota G, Fuertes AB (2007) Saccharide-based graphitic carbon nanocoils as supports for PtRu nanoparticles for methanol electrooxidation. J Power Sources 171(2):546-551. https:// doi.org/10.1016/j.jpowsour.2007.05.096

38. Maya-Cornejo J, Arjona N, Guerra-Balcázar M, Álvarez-Contreras L, Ledesma-García J, Arriaga LG (2014) Synthesis of Pd-Cu bimetallic electrocatalyst for ethylene glycol and glycerol oxidations in alkaline media. Proc Chem 12:19-26. https://doi.org/10. 1016/j.proche.2014.12.036

39. Arjona N, Guerra-Balcazar M, Cuevas-Muniz FM, Alvarez-Contreras L, Ledesma- Garcia J, Arriaga LG (2013) Electrochemical synthesis of flower-like Pd nanoparticles with high Tolerance toward formic acid electrooxidation. Rsc Adv 3(36):1572715733. https://doi.org/10.1039/C3RA41681J

40. Duan D, Wang Q, Liu H, You X, Liu S, Wang YJ (2016) Investigation of carbon-supported Ni@Ag core-shell nanoparticles as electrocatalyst for electrooxidation of sodium borohydride. Solid State Chem 20(10):2699-2711. https://doi.org/10.1007/ s10008-016-3285-5

41. Maringa A, Mashazi P, Nyokong T (2015) Electrocatalytic activity of bimetallic $\mathrm{Au}-\mathrm{Pd}$ nanoparticles in the presence of cobalt tetraaminophthalocyanine. J Colloid Interface Sci 440:151-161. https://doi.org/10.1016/j.jcis.2014.10.056

42. Bard AJ, Faulkner LR (2001) Fundamentals and applications. Electrochem Method 2(482):580-632

43. Huang L, Han Y, Zhang X, Fang Y, Dong S (2017) One-step synthesis of ultra thin $\mathrm{PtxPb}$ nerve-like nanowires as robust catalysts for enhanced methanol electrooxidation. Nanoscale 9(1):201-207. https://doi.org/10.1039/C6NR07036A

44. Xu H, Yan B, Zhang K, Wang J, Li S, Wang C, Xiong Z, Shiraishi Y, Du Y (2017) Self supported worm like PdAg nanoflowers as efficient electrocatalysts towards ethylene glycol oxidation. Chem Electron Chem 4(10):2527-2534. https://doi.org/10.1002/celc. 201700611

45. Hansu TA, Caglar A, Sahin O, Kivrak H (2020) Hydrolysis and electrooxidation of sodium borohydride on novel CNT supported CoBi fuel cell catalyst. Mater Chem Phys 239:122031. https:// doi.org/10.1016/j.matchemphys.2019.122031

46. Wang K, Lu J, Zhuang L (2005) Direct determination of diffusion coefficient for borohydride anions in alkaline solutions using chronoamperometry with spherical Au electrodes. J Electroanal Chem 585(2):191-196. https://doi.org/10.1016/j.jelechem.2005. 08.009

Publisher's Note Springer Nature remains neutral with regard to jurisdictional claims in published maps and institutional affiliations. 